\title{
Settling the browser-grazer debate for African buffalo in grass-limited Eastern Cape thicket, South Africa
}

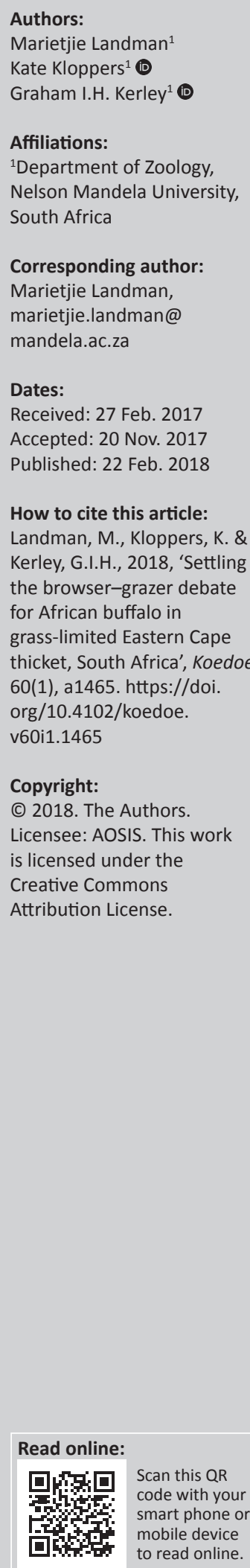

\begin{abstract}
Despite extensive evidence that African buffalo Syncerus caffer are grazers, De Graaff et al. using rumen content analysis of animals that had starved to death proposed that buffalo in grass-limited Eastern Cape thicket should be considered browsers. Although these anomalous findings were initially accepted, but later challenged, the browse-dominated diet continues to be used as a foundation for hypotheses on the diet of healthy animals. Consequently, the debate around buffalo as browsers or grazers in thicket has not yet been settled. We describe the diet of buffalo in the Addo Elephant National Park and include data from other published work from the region to test the importance of grass in buffalo diet. We show that the diet is dominated by grasses, even in grass-limited thicket, and that browse species are seldom dominant foods. Thus, there is no empirical evidence to corroborate the notion that buffalo switch their diet to browse when grass availability is low. In an attempt to advance our understanding of buffalo foraging in thicket, we reiterate that De Graaff's work is not a valid measure of buffalo diet in succulent thicket and that additional testing of the browser-grazer hypothesis is not needed.
\end{abstract}

Conservation implications: Our results confirm that buffalo are grazers, rather than browsers, in grass-limited Eastern Cape thicket. Thus, additional testing of the browser-grazer hypothesis for buffalo in the region is not needed.

\section{Introduction}

Weak attempts to apply the scientific method may paradoxically improve our understanding if these encourage further robust scientific engagement that recognises the pitfalls of earlier attempts (e.g. Hayward et al. 2015; Stephens et al. 2015). Here we use an example of a diet study of African buffalo Syncerus caffer that had starved to death (De Graaff, Schulz \& Van der Walt 1973), and whose findings were anomalous and initially accepted, only to be challenged later (Landman \& Kerley 2001; Novellie, Hall-Martin \& Joubert 1991). With this we aim to resolve the debate around buffalo as browsers or grazers in grass-limited Eastern Cape thicket, South Africa.

Based on their digestive anatomy, Hofmann (1989) classified large ruminant herbivores along a continuum from browsers through intermediate feeders to grazers. Following this classification, buffalo are specialist grazers, adapted to forage on grasses (as opposed to browse for browsers, or a mixture of grass and browse for intermediate feeders) that are rich in plant cell walls (or fibre). Although both the nutritional and physiological bases of Hofmann's classification have been questioned (e.g. Gordon \& Illius 1994; Robbins, Spalinger \& Van Hoven 1995), most empirical evidence of the food of buffalo corresponds neatly with the grazing-type digestive system. Thus, across their range in eastern and southern Africa, buffalo diet is dominated by grasses (e.g. Cerling, Harris \& Passey 2003; Codron et al. 2007; Jarman 1971; Lamprey 1963; Perrin \& Brereton-Stiles 1999; Prins 1996; Sinclair 1977). However, in the succulent thickets of the Eastern Cape, De Graaff et al. (1973), using rumen content analysis of buffalo that had died in a drought, showed an overabundance of browse in buffalo diet. They presumed that this was a response to low grass availability at the time and proposed that these buffalo should be considered browsers rather than grazers. This led to a number of studies on the food of buffalo in the region (Landman \& Kerley 2001; Tshabalala, Dube \& Lent 2009; Watermeyer, Carroll \& Parker 2015), each aimed at testing the extent to which buffalo switch their diet between browse and grass. Importantly, Landman and Kerley (2001) concluded that De Graaff's methods were inappropriate for testing diet because their study animals died during a pronounced drought and probably as a consequence of excessive browse to which they were not adapted (Novellie et al. 1991). Despite this, De Graaff's browsedominated diet continues to be used as a foundation for hypotheses on the diet of healthy animals (Tshabalala et al. 2009; Watermeyer et al. 2015). As a consequence, the debate around the feeding strategy of buffalo in thicket has not yet been settled. 
Here we describe the diet of buffalo in the grass-limited succulent thickets of the Addo Elephant National Park. The specific question addressed was how important is grass in buffalo diet in thicket, taking into account other published work from the study site and region (De Graaff et al. 1973; Landman \& Kerley 2001; Tshabalala et al. 2009; Watermeyer et al. 2015). To end off, we consider how our findings influence research perspectives on buffalo resource use in succulent thicket specifically.

\section{Methods}

\section{Study site}

We conducted the study in the Main Camp section (then covering $120 \mathrm{~km}^{2}$ ) of the Addo Elephant National Park, South Africa. During the study, the area supported roughly 300 buffalo and a diverse grazing herbivore community of plains zebra Equus quagga, common warthog Phacochoerus africanus, eland Tragelaphus oryx and red hartebeest Alcelaphus buselaphus, and numerous browsers.

The region is semi-arid with $260 \mathrm{~mm}-530 \mathrm{~mm}$ rainfall annually (333 $\mathrm{mm}$ over the study period), peaking in late spring (November) and early autumn (March) and experiences frequent droughts. Vegetation comprises mostly succulent thicket types (70\%), which are evergreen, $2 \mathrm{~m}-4 \mathrm{~m}$ high and dominated by the tree-succulent Portulacaria afra (Mucina \& Rutherford 2006). These thickets are characterised by a high diversity of growth forms: drought-resistant succulents (e.g. P. afra), low trees (e.g. Euclea undulata, Schotia afra and Sideroxylon inerme) and spinescent woody shrubs (e.g. Azima tetracantha, Capparis sepiaria, Carissa spp., Gymnosporia spp. and Searsia spp.) contribute the bulk of plant biomass, whereas the understory hosts dwarf succulents, forbs and geophytes. Although grass availability is generally low and unreliable between years (Stuart-Hill \& Aucamp 1993), some species (e.g. Cynodon dactylon, Digitaria eriantha, Eragrostis spp., Panicum spp. and Sporobolus spp.) may be seasonally abundant in secondary grasslands (covering roughly 15\% of the study site) and where intensive utilisation by elephants has removed the canopy shrubs (Landman et al. 2014).

\section{Diet composition}

We determined the diet of buffalo by identifying plant epidermal fragments in faeces (Sparks \& Malechek 1968). Reference slides of the epidermal tissues of potential food items at the site were available from Landman and Kerley (2001) and Landman, Schoeman and Kerley (2008). Holechek, Vavra and Pieper (1982) described the accuracies and biases of the technique.

Between January and September 2007, we collected 15 fresh faecal samples in each of the four austral seasons, for a total of 60 samples. Seasons were identified based on patterns of temperature, rainfall and frost. Faeces were collected opportunistically from apparently healthy buffalo in family groups located throughout the study site, oven-dried and prepared following Landman and Kerley (2001) and Landman et al. (2008). We identified 100 epidermal fragments to species-level per faecal sample and treated each sample as an independent observation. The diet is described as the frequency of occurrence of all the recorded plant species.

\section{Data analyses}

To assess the adequacy of our sample size, we generated a mean randomised (50 iterations) accumulation curve of plant species recorded per faecal sample. However, because this curve did not reach a clear asymptote, we estimated total dietary richness with a non-parametric species richness estimator (Foggo et al. 2003). Differences between observed and expected counts provide an estimate of the variation in dietary information at the upper limit of sampling effort.

We generally combined the seasonal data and described the diet in terms of principal diet items and by grouping all plant species into broad growth form categories (i.e. grasses, woody shrubs, succulents, forbs and climbers). Principal diet items are those foods consumed in the greatest quantities and were identified as the plant species that contributed $>3 \%$ of the diet (Landman \& Kerley 2001; Tshabalala et al. 2009). ANOVA procedures (Tukeys' test) were used to test for differences in growth form categories and the number of plant species recorded in the diet across seasons. Data were inspected for deviations from normality and homogeneity of variances prior to analyses.

To develop broader insight into the range of buffalo diet in succulent thicket, we draw data from two previous studies at the study site (De Graaff et al. 1973; Landman \& Kerley 2001) and two others in the region (Great Fish River Nature Reserve - Tshabalala et al. 2009; Kwandwe Private Game Reserve - Watermeyer et al. 2015). Because De Graaff's study animals died during a drought, we use their data only to support the presence of plant species already recorded.

\section{Results and discussion}

This study identified 37 plant species in the diet of buffalo in 60 faecal samples (Table 1). These species accounted for roughly $79 \%$ of the estimated richness at the upper limit of sampling effort, suggesting that our sample size was adequate to describe the diet. Although the observed richness is comparable to that recorded previously (e.g. Landman \& Kerley 2001; Tshabalala et al. 2009; Venter \& Watson 2008), 17 species were new to the diet in thicket and the study site specifically (Table 1). Importantly, $>80 \%$ of the browse species recorded in the rumen samples of De Graaff et al. (1973) were not recorded in the diet anywhere else in the region. By combining our data with those from others in the region (Landman \& Kerley 2001; Tshabalala et al. 2009), we show that buffalo have a relatively broad diet -44 plant species - exceeding that of other grass-eating ruminants in thicket (e.g. eland, red hartebeest - Kerley \& Landman 2006). 
TABLE 1: Plant species identified in the diet of buffalo in the succulent thickets of the Eastern Cape, South Africa.

\begin{tabular}{|c|c|c|c|}
\hline Plant family & Plant species & $\begin{array}{c}\% \text { Diet } \\
\text { (mean } \pm \text { s.d.) }\end{array}$ & $\begin{array}{c}\text { Previously recorded } \\
\text { in the diet }\end{array}$ \\
\hline \multicolumn{4}{|l|}{ Grasses } \\
\hline \multirow[t]{20}{*}{ Poaceae } & Aristida diffusa & $2.8 \pm 3.0$ & 2 \\
\hline & Cenchrus ciliaris & $10.2 \pm 6.2$ & 2 \\
\hline & Cymbopogon pospischilii & $5.6 \pm 3.0$ & 2,3 \\
\hline & Cynodon dactylon & $3.7 \pm 2.7$ & 2,3 \\
\hline & Digitaria eriantha & - & 3 \\
\hline & Eragrostis curvula & $8.3 \pm 4.7$ & 2,3 \\
\hline & Eragrostis obtusa & $4.0 \pm 3.7$ & 2,3 \\
\hline & Eustachys paspaloides & $5.4 \pm 3.8$ & - \\
\hline & Fingerhuthia africana & $4.1 \pm 3.7$ & - \\
\hline & Melica decumbens & $1.1 \pm 1.6$ & - \\
\hline & Melinis repens & - & 2 \\
\hline & Panicum deustum & $13.6 \pm 3.0$ & 2,3 \\
\hline & Panicum maximum & $1.3 \pm 2.4$ & - \\
\hline & Pennisetum clandestinum & $5.5 \pm 4.5$ & 2 \\
\hline & Setaria neglecta & - & 3 \\
\hline & Setaria sphacelata & $0.1 \pm 0.7$ & - \\
\hline & Sporobolus fimbriatus & $3.2 \pm 2.6$ & 3 \\
\hline & Stipa dregeana & $2.0 \pm 3.1$ & - \\
\hline & Themeda triandra & $4.7 \pm 3.3$ & 2,3 \\
\hline & Tragus berteronianus & $<0.1 \pm 0.3$ & - \\
\hline \multicolumn{4}{|l|}{ Woody shrubs } \\
\hline \multirow[t]{5}{*}{ Anacardiaceae } & Searsia longispina & $12.7 \pm 8.6$ & 2 \\
\hline & Asparagus crassicladus & $0.9 \pm 1.6$ & 2 \\
\hline & Asparagus striatus & $5.3 \pm 3.8$ & 1 \\
\hline & Asparagus suaveolens & $0.1 \pm 0.6$ & 2 \\
\hline & Asparagus sp. & $0.4 \pm 2.5$ & - \\
\hline Boraginaceae & Ehretia rigida subsp. silvatica & $<0.1 \pm 0.1$ & - \\
\hline \multirow[t]{3}{*}{ Capparaceae } & Cadaba aphylla & - & 2 \\
\hline & Capparis sepiaria var. citrifolia & $1.8 \pm 3.2$ & $1,2,3$ \\
\hline & Maerua cafra & $0.1 \pm 0.5$ & - \\
\hline Celastraceae & Gymnosporia capitata & $0.1 \pm 0.5$ & - \\
\hline Ebenaceae & Euclea undulata & - & 1,3 \\
\hline Euphorbiaceae & Clutia affinis & $1.6 \pm 2.4$ & - \\
\hline Fabaceae & Acacia karroo & $0.1 \pm 0.4$ & 2,3 \\
\hline Malvaceae & Grewia robusta & $0.1 \pm 0.3$ & 2,3 \\
\hline Salicaceae & Dovyalis caffra & $0.2 \pm 0.7$ & - \\
\hline Plumbaginaceae & Plumbago auriculata & - & 3 \\
\hline Ptaeroxylaceae & Ptaeroxylon obliquum & $<0.1 \pm 0.3$ & 2,3 \\
\hline Solanaceae & $\begin{array}{l}\text { Solanum tomentosum var. } \\
\text { tomentosum }\end{array}$ & $0.2 \pm 0.8$ & - \\
\hline \multicolumn{4}{|l|}{ Succulents } \\
\hline \multirow[t]{2}{*}{ Crassulaceae } & Crassula ovata & $<0.1 \pm 0.3$ & 2 \\
\hline & $\begin{array}{l}\text { Crassula perforata subsp. } \\
\text { perforata }\end{array}$ & $0.5 \pm 1.7$ & - \\
\hline Euphorbiaceae & Euphorbia sp. & $0.1 \pm 0.4$ & - \\
\hline Portulacaceae & Portulacaria afra & $0.2 \pm 1.0$ & $1,2,3$ \\
\hline \multicolumn{4}{|l|}{ Climbers } \\
\hline Cucurbitaceae & Kedrostis nana var. zeyheri & - & 2 \\
\hline Vitaceae & Rhoicissus tridentata & $0.1 \pm 0.4$ & - \\
\hline
\end{tabular}

Note: Please see the full reference list of the article, Landman, M., Kloppers, K. \& Kerley, G.I.H., 2018, 'Settling the browser-grazer debate for African buffalo in grass-limited Eastern Cape thicket, South Africa', Koedoe 60(1), a1465. https://doi.org/10.4102/koedoe. v60i1.1465, for more information.

For this study, we present the mean percent contribution to the diet \pm s.d. and include information on the presence or absence of plant species from (1) De Graaff et al. (1973), (2) Landman and Kerley (2001) and (3) Tshabalala et al. (2009).

Bold values show principal diet items.

Thus, buffalo foraging may rely on more plant species than previously thought, and we contribute towards understanding its role in succulent thicket and the Addo Elephant National Park specifically.
Based on their characteristic grazing-type digestive system (Hofmann 1989), grasses contributed the bulk of the diet $($ mean $=75.6 \%$, s.d. $=12.7 \%)$ in our study. The remaining browse comprised woody $($ mean $=23.6 \%$, s.d. $=12.2 \%$ ) and succulent $($ mean $=0.8 \%$, s.d. $=2.2 \%$ ) shrubs and climbers (mean $=0.1 \%$, s.d. $=0.4 \%)$, with few browse species contributing sufficiently to the diet to be considered dominant (i.e. > 3\%). Instead, principal diet items were characterised by grasses across study populations (Table 1). Our results are within the range of mean grass consumption by buffalo in the region $(71.9 \%$ - Landman \& Kerley 2001; $\pm 75 \%$ - Tshabalala et al. 2009; 93.1\% - Watermeyer et al. 2015) and support all previous work on their food resources (e.g. Cerling et al. 2003; Codron et al. 2007; Jarman 1971; Lamprey 1963; Perrin \& Brereton-Stiles 1999; Prins 1996; Sinclair 1977), including that from other grass-limited habitats (Venter \& Watson 2008) considered marginal to buffalo (i.e. Nama-Karoo, Boshoff, Landman \& Kerley 2016).

Seasonal variations in diet are well described, particularly as buffalo increase their utilisation of browse towards the dry season when grass availability and quality decline (e.g. Prins 1996; Sinclair 1977; Tshabalala et al. 2009; Watermeyer et al. 2015). Although we found no seasonal differences in the contribution of browse to the diet in our study (range across seasons: $\left.19.7 \%-30.0 \% ; F_{3,56}=2.25, P=0.09\right)$, we detected a gradual increase in diet breadth (from 19 spp. to $35 \mathrm{spp}$.) towards the dry season that coincided with an increase in the utilisation of browse species (from 26\% [spring] to 54\% [summer] of plant species recorded; $F_{3,56}=4.22, P=0.009$ ). These findings follow the predictions of optimality theory which predicts that a loss of preferred foods (such as grasses for buffalo - Prins 1996; Sinclair 1977) would cause an increase in the utilisation of less nutritious, non-preferred foods (Owen-Smith \& Novellie 1982). Thus, despite the fact that we had no information on food availability and could not test food preferences per se, we presume that the broader diet and increased utilisation of browse species during the dry season reflects changing diet with changing grass availability and quality.

From our results, it is clear that buffalo diet is dominated by grasses, even in grass-limited succulent thicket (Landman \& Kerley 2001; Tshabalala et al. 2009; Watermeyer et al. 2015). Although the diet might include browse in varying quantity between seasons, depending on the availability and quality of grass, browse species are seldom dominant foods and many are probably incidentally utilised as parts of larger mouthfuls. Thus, with the exception of the findings of De Graaff et al. (1973), there is no empirical evidence to support the notion that buffalo switch their diet to browse when grass availability is low (Cerling et al. 2003; Codron et al. 2007; Jarman 1971; Lamprey 1963; Perrin \& Brereton-Stiles 1999; Prins 1996; Sinclair 1977; Venter \& Watson 2008). Instead, De Graaff's work generated confusion in our understanding of buffalo foraging in thicket through poor experimental design. Even though such weaknesses can undermine science and management (e.g. Hayward et al. 2015; Stephens et al. 2015), 
this might still improve our understanding if it encourages additional robust interrogation. For buffalo in thicket, additional testing confirmed what was already known about their diet, which probably limited our ability to develop broader insights because our approaches were motivated by a single hypothesis. Thus, in an attempt to advance our understanding of buffalo foraging in thicket, we reiterate the conclusions of Landman and Kerley (2001) that De Graaff's work is not a valid measure of buffalo diet in succulent thicket and that additional testing of the browser-grazer hypothesis is not needed.

\section{Conclusion}

Our study questioned the importance of grass in buffalo diet in grass-limited Eastern Cape thicket. We show that the diet is dominated by grasses, even in grass-limited thicket, and that browse species are seldom dominant foods. Thus, there is no empirical evidence to corroborate the notion that buffalo switch their diet to browse when grass availability is low. With this we argue that additional testing of the browsergrazer hypothesis for buffalo in the region is not needed.

\section{Acknowledgements}

The authors thank South African National Parks for providing permission to conduct this study.

\section{Competing interests}

The authors declare that they have no financial or personal relationships that may have inappropriately influenced them in writing this article.

\section{Authors' contributions}

M.L., K.K. and G.I.H.K. designed the study, analysed the data and wrote the article.

\section{References}

Boshoff, A., Landman, M. \& Kerley, G.I.H., 2016, 'Filling the gaps on the maps: Historical distribution patterns of some of the larger mammals in part of southern Africa', Transactions of the Royal Society of South Africa 71, 23-87. https://doi.org/10.1080/0035919X.2015.1084066

Cerling, T., Harris, J. \& Passey, B., 2003, 'Diets of East African Bovidae based on stable isotope analysis', Journal of Mammalogy 84, 456-470. https://doi.org/10.1644/ 1545-1542(2003)084\%3C0456:DOEABB\%3E2.0.CO;2

Codron, D., Codron, J., Lee-Thorp, J.A., Sponheimer, M., De Ruiter, D., Sealy, J. et al. 2007, 'Diets of savanna ungulates from stable carbon isotope composition of faeces', Journal of Zoology, London 273, 21-29. https://doi.org/10.1111/j.146979eces', Journal of Zoor

De Graaff, G., Schulz, K.C.A. \& Van der Walt, P.T., 1973, 'Notes on rumen contents of Cape buffalo Syncerus caffer in the Addo Elephant National Park', Koedoe 16, 45-58. https://doi.org/10.4102/koedoe.v16i1.884
Foggo, A., Attrill, M.J., Frost, M.T. \& Rowden, A.A., 2003, 'Estimating marine species richness: An evaluation of six extrapolative techniques', Marine Ecology Progress richness: An evaluation of six extrapolative techniques',
Series 248, 15-26. https://doi.org/10.3354/meps248015

Gordon, I.J. \& Illius, A.W., 1994, 'The functional significance of the browser-grazer dichotomy in African ruminants', Oecologia 98, 167-175. https://doi.org/10.1007/ BF00341469

Hayward, M.H., Boitani, L., Burrows, N.D., Funston, P.J., Ullas Karath, K., Mackenzie, D.I. et al., 2015, 'Ecologists need robust survey designs, sampling and analytical methods', Journal of Applied Ecology 52, 286-290. https://doi.org/10.1111/13652664.12408

Hofmann, R.R., 1989, 'Evolutionary steps of ecophysiological adaptation and diversification of ruminants: A comparative view of their digestive system' Oecologia 78, 443-457. https://doi.org/10.1007/BF00378733

Holechek, J.L., Vavra, M. \& Pieper, R.D., 1982, 'Botanical composition determination of range herbivore diets: A review', Journal of Range Management 35, 309-315. https://doi.org/10.2307/3898308

Jarman, P.J., 1971, 'Diets of large mammals in the woodlands around lake Kariba, Rhodesia', Oecologia 8, 157-178. https://doi.org/10.1007/BF00345811

Kerley, G.I.H. \& Landman, M., 2006, 'The impacts of elephants on biodiversity in the Eastern Cape subtropical thickets', South African Journal of Science 102, 395-402.

Lamprey, H.F., 1963, 'Ecological separation of the large mammal species in the Tarangire Game Reserve, Tanganyika', East Africa Wildlife Journal 1, 63-92. https://doi.org/10.1111/j.1365-2028.1963.tb00179.x

Landman, M. \& Kerley, G.I.H., 2001, 'Dietary shifts: Do grazers become browsers in the thicket biome?', Koedoe 44, 31-36. https://doi.org/10.4102/koedoe.v44i1.183

Landman, M., Kerley, G.I.H. \& Schoeman, D.S., 2008, 'Relevance of elephant herbivory as a threat to important plants in the Addo Elephant National Park, South Africa', Journal of Zoology, London 274, 51-58.

Landman, M., Schoeman, D.S., Hall-Martin, A.J. \& Kerley, G.I.H., 2014, 'Long-term monitoring reveals differing impacts of elephant on elements of a canopy shrub community', Ecological Applications 24, 2002-2012. https://doi.org/10.1890/140080.1

Mucina, L. \& Rutherford, M.C., 2006, 'The vegetation of South Africa, Lesotho and Swaziland', Strelitzia 19, 1-807.

Novellie, P., Hall-Martin, A.J. \& Joubert, D., 1991, 'The problem of maintaining large herbivores in small conservation areas: Deterioration of the grassveld in the Addo Elephant National Park', Koedoe 34, 41-50. https://doi.org/10.4102/koedoe. v34i1.413

Owen-Smith, N. \& Novellie, P., 1982, 'What should a clever ungulate eat?', American Naturalist 119, 151-178. https://doi.org/10.1086/283902

Perrin, M.R. \& Brereton-Stiles, R., 1999, 'Habitat use and feeding behavior of the buffalo and the white rhinoceros in the Hluhluwe-Umfolozi Game Reserve', South African Journal of Wildlife Research 29, 72-80.

Prins, H.H.T., 1996, Ecology and behavior of the African buffalo, Chapman \& Hall, London.

Robbins, C.T., Spalinger, D.E. \& Van Hoven, W., 1995, 'Adaptation of ruminants to browse and grass diets: Are anatomical-based browser-grazer interpretations valid?', Oecologia 103, 208-213. https://doi.org/10.1007/BF00329082

Sinclair, A., 1977, The African buffalo: A study of resource limitation of populations, University of Chicago Press, Chicago, IL.

Sparks, D.R. \& Malechek, J.C., 1968, 'Estimating percentage dry weight in diets using a microscopic technique', Journal of Range Management 21, 264-265. https://doi. org/10.2307/3895829

Stephens, P.A., Pettorelli, N., Barlow, J., Whittingham, M.J. \& Cadotte, M.W., 2015 'Management by proxy? The use of indices in applied ecology', Journal of Applied Ecology 52, 1-6. https://doi.org/10.1111/1365-2664.12383

Stuart-Hill, G.C. \& Aucamp, A.J., 1993, 'Carrying capacity of the succulent valley bushveld of the Eastern Cape', African Journal of Range and Forage Science 10 1-10. https://doi.org/10.1080/10220119.1993.9638314

Tshabalala, T., Dube, S. \& Lent, P.C., 2009, 'Seasonal variation in forages utilized by the African buffalo (Syncerus caffer) in the succulent thicket of South Africa', African Journal of Ecology 48, 438-445. https://doi.org/10.1111/j.1365-2028.2009. 01132.x

Venter, J.A. \& Watson, L.H., 2008, 'Feeding and habitat use of buffalo (Syncerus caffer caffer) in the Nama-Karoo, South Africa', South African Journal of Wildlife Research 38, 42-51. https://doi.org/10.3957/0379-4369-38.1.42

Watermeyer, J.P., Carroll, S.L. \& Parker, D.M., 2015, 'Seasonal consumption of browse by the African buffalo (Syncerus caffer) in Thicket Biome of South Africa', African Journal of Ecology 53, 599-601. https://doi.org/10.1111/aje.12214 